\title{
Immune reaction against the cytoskeleton in coeliac disease
}

\author{
M G Clemente, M P Musu, F Frau, G Brusco, G Sole, G R Corazza, S De Virgiliis
}

Dipartimento di Scienze Biomediche e Biotecnologie, Servizio delle Malattie

Metaboliche del

Bambino, Università

degli Studi di Cagliari,

Cagliari, Italy

M G Clemente

M P Musu

F Frau

$S$ De Virgiliis

IRCCS Policlinico "S Matteo", Divisione di Gastroenterologia, Università degli Studi di Pavia, Pavia, Italy

G Brusco

G R Corazza

Istituto di Ricerca sulle Talassemie ed Anemie Mediterranee, Consiglio Nazionale delle Ricerche,

Cagliari, Italy

G Sole

Correspondence to: Professor S De Virgiliis, Servizio delle Malattie Metaboliche del Bambino, Centro Regionale per le Microcitemie, via Jenner, 09121, Cagliari, Italy. Email: sdevirgi@mcweb.unica.it

Accepted for publication 4 April 2000

\begin{abstract}
Background-The cytoskeleton actin network of intestinal microvilli has been found to be rapidly impaired after gluten challenge in coeliac disease (CD). The aim of this study was to investigate the presence of an immune reaction towards cytoskeleton structures such as actin filaments in CD.

Methods-Eighty three antiendomysial antibody positive CD patients ( 52 children and 31 adults) were studied at our outpatient clinics from 1996 to 1998 using indirect immunofluorescence, ELISA, and western blotting for antiactin (AAA) and antitissue transglutaminase (TGA) antibodies before and after a gluten free diet (GFD). Sixteen patients with smooth muscle antibody positive autoimmune hepatitis, 21 with inflammatory bowel diseases, seven with small bowel bacterial overgrowth, and 60 healthy subjects were studied as controls.

Results-Fifty nine of 83 CD patients $(28 / 31$ adults $(90.3 \%) ; 31 / 52$ children $(59.6 \%)$ ) were positive for IgA and/or IgG AAA. Seventy seven $(92.7 \%)$ were positive for IgA TGA. IgA AAA were strongly correlated with more severe degrees of intestinal villous atrophy $(\mathrm{p}<0.0001$; relative risk 86.17). After a GFD, AAA became undetectable within five months.

Conclusions-Apart from the immune reaction against the extracellular matrix, we have described an immune reaction against the cytoskeleton in both children and adults with CD. As AAA are strongly associated with more severe degrees of villous atrophy, they may represent a useful serological marker of severe intestinal atrophy in CD.

(Gut 2000;47:520-526)
\end{abstract}

Keywords: coeliac disease; autoantibody; intestinal villous atrophy; cytoskeleton; actin; smooth muscle

Coeliac disease (CD) is a gluten sensitive enteropathy characterised by inflammation of the small bowel mucosa, with various degrees of intestinal villous atrophy and crypt hyperplasia, and by circulating antibodies (IgA and IgG class antigliadin (AGA), IgA antireticulin (ARA), and antiendomysium (AEA)).$^{1-3}$ Its clinical presentation is highly variable, ranging from silent to fully expressed intestinal malabsorption. ${ }^{4}$ A strong association with HLA-DQ $2^{5}$ and a high prevalence of autoimmune diseases, such as insulin dependent diabetes mellitus and Hashimoto's thyroiditis, are typical CD features. ${ }^{6}$ According to the ESPGHAN criteria, a diagnosis of CD is based on the histological picture and confirmed by demonstration of gluten dependence of the clinical symptoms and circulating antibodies. ${ }^{7}$ Still largely unknown are the pathogenetic mechanisms by which dietary gluten in CD patients gives rise to the histological picture of flat mucosa, characterised by tissue destruction and reorganisation of the surface epithelium, basal lamina, and structures of the extracellular matrix. $^{8}$

Recently, tissue transglutaminase (tTG) has been identified as the major endomysial autoantigen $^{9}$ and evidence has been produced that deamidation of gliadin by tTG may enhance the recognition of gliadin peptides by HLA DQ2/8 T cells in genetically predisposed subjects and initiate the autoimmune disease. ${ }^{10}$ Possible explanations for the matrix remodelling and mucosal damage in CD have been put forward. Activation of gliadin induced $\mathrm{T}$ cells could be responsible for mucosal destruction through production of cytokines and matrix metalloproteinases. ${ }^{11} 12$

The involvement of the cytoskeleton in CD has been reported, ${ }^{13}$ and gluten challenge has been shown to cause rapid disappearance and disorganisation of actin filaments on the intestinal mucosa from CD patients. ${ }^{14}{ }^{15}$ Furthermore, it has been shown recently that in human vascular smooth muscle cells, more than $40 \%$ of tTG activity colocalised with actin stress fibres. ${ }^{16}$

The aim of this study was to investigate if a humoral immune reaction against actin, a key structural protein of the cytoskeleton network that is particularly abundant in intestinal microvilli, ${ }^{17}$ is present in CD.

\section{Materials and methods}

PATIENTS

Eighty three biopsy proven coeliac patients, 52 children (mean age 5.9 (3.6) years, range 1-15; $\mathrm{M} / \mathrm{F} 20 / 32$ ) and 31 adults (mean age 31.1 (11.0) years, range $17-64 ; \mathrm{M} / \mathrm{F} 5 / 26$ ) were included in the study. Nineteen patients had

Abbreviations used in this paper: AAA, antiactin antibodies; GFD, gluten free diet; AEA, antiendomysium antibodies; AGA, antigliadin antibodies; $\mathrm{AH}$, autoimmune hepatitis; IBD, inflammatory bowel disease; AMA, antimitochondrial antibodies; IF, indirect immunofluorescence; ANA, antinuclear antibodies; ANCA, antineutrophil cytoplasm antibodies; ARA, antireticulin antibodies; CD, coeliac disease; LC-1, antiliver cytosol 1 antibodies; LKM, antiliver kidney microsome antibodies; SMA, smooth muscle antibodies; PBS, phosphate buffered saline; SLA, antisoluble liver antigen antibodies; TGA, antitransglutaminase antibodies; tTG, tissue transglutaminase; $R R$, relative risk. 
Table 1 Major serological, clinical, and histological features of antiactin antibody (AAA) positive children with coeliac disease

\begin{tabular}{|c|c|c|c|c|c|c|c|c|}
\hline $\begin{array}{l}\text { Patient } \\
\text { No }\end{array}$ & $\begin{array}{l}\text { Age (y) at } \\
\text { diagnosis }\end{array}$ & $\begin{array}{l}\text { AEA IgA } \\
\text { titre }\end{array}$ & $\begin{array}{l}\text { TGA IgA } \\
\text { titre }\end{array}$ & $\begin{array}{l}\text { AAA } \operatorname{Ig} A \\
\text { titre }\end{array}$ & $\begin{array}{l}\text { AAA } \operatorname{Ig} G \\
\text { titre }\end{array}$ & Liver disease & $D V A$ & $\begin{array}{l}\text { Months of } A A A \\
\text { negativity }^{*}\end{array}$ \\
\hline 1 & 1 & Negative & 0.038 & Negative & $1: 160$ & Absent & Severe & nd \\
\hline 2 & 1 & $1: 5$ & 0.063 & 1:40 & $1: 40$ & $\uparrow A L T$ & Severe & 2 \\
\hline 3 & 1 & $1: 160$ & 0.121 & $1: 40$ & Negative & Absent & Moderate & 2 \\
\hline 4 & 1 & $>1: 1280$ & 0.895 & $1: 640$ & $1: 640$ & $\uparrow$ ALT & Severe & 3 \\
\hline 5 & 2 & $>1: 1280$ & 0.990 & $1: 160$ & $1: 640$ & 个ALT & Severe & 4 \\
\hline 6 & 2 & $>1: 1280$ & 0.575 & Negative & $1: 40$ & Absent & Moderate & 2 \\
\hline 7 & 2 & $>1: 1280$ & 0.087 & Negative & $1: 160$ & Absent & Severe & 3 \\
\hline 8 & 2 & $>1: 1280$ & 0.475 & $1: 640$ & $1: 640$ & 个ALT & Severe & 4 \\
\hline 9 & 3 & $>1: 1280$ & 1.250 & $1: 640$ & $1: 640$ & $\uparrow A L T$ & Severe & 3 \\
\hline 10 & 3 & $>1: 1280$ & 0.830 & $>1: 1280$ & Negative & 个ALT & Moderate & 3 \\
\hline 11 & 3 & 1:640 & 0.206 & Negative & $1: 640$ & Absent & Moderate & 4 \\
\hline 12 & 4 & $>1: 1280$ & 1.135 & $1: 160$ & Negative & Absent & Moderate & 2 \\
\hline 13 & 4 & $>1: 1280$ & 1.370 & $1: 320$ & Negative & Absent & Severe & 3 \\
\hline 14 & 4 & $>1: 1280$ & 1.200 & $>1: 1280$ & Negative & Absent & Severe & 4 \\
\hline 15 & 5 & $1: 640$ & 0.105 & Negative & $1: 640$ & Absent & Moderate & 5 \\
\hline 16 & 6 & $>1: 1280$ & 0.930 & $1: 160$ & Negative & Absent & Severe & 2 \\
\hline 17 & 6 & $>1: 1280$ & 1.473 & $1: 160$ & $1: 160$ & $\uparrow$ ALT & Severe & 2 \\
\hline 18 & 7 & $>1: 1280$ & 0.478 & Negative & $1: 160$ & $\uparrow$ ALT & Severe & 2 \\
\hline 19 & 7 & $>1: 1280$ & 1.273 & $1: 640$ & Negative & Absent & Severe & 3 \\
\hline 20 & 7 & $>1: 1280$ & 0.515 & $1: 40$ & Negative & Absent & Severe & 3 \\
\hline 21 & 7 & $1: 160$ & 0.128 & Negative & $1: 160$ & Absent & Severe & 3 \\
\hline 22 & 7 & $>1: 1280$ & 0.980 & $1: 640$ & $1: 640$ & Absent & Severe & 3 \\
\hline 23 & 8 & $>1: 1280$ & 1.328 & $>1: 1280$ & Negative & Absent & Severe & 4 \\
\hline 24 & 9 & $>1: 1280$ & 1.000 & $1: 640$ & Negative & Absent & Severe & 3 \\
\hline 25 & 9 & $>1: 1280$ & 0.436 & $1: 40$ & Negative & Absent & Severe & 2 \\
\hline 26 & 10 & $>1: 1280$ & 0.850 & $1: 160$ & Negative & Absent & Severe & 3 \\
\hline 27 & 12 & $>1: 1280$ & 0.422 & $1: 40$ & Negative & Absent & Severe & 2 \\
\hline 28 & 14 & $>1: 1280$ & 1.485 & $1: 640$ & Negative & Absent & Severe & 4 \\
\hline 29 & 14 & $1: 640$ & 0.210 & Negative & $1: 160$ & $\mathrm{CH}$ & Severe & 3 \\
\hline 30 & 14 & $>1: 1280$ & 0.870 & $>1: 1280$ & Negative & 个ALT & Severe & 4 \\
\hline 31 & 15 & $>1: 1280$ & 0.960 & $>1: 1280$ & Negative & 个ALT & Severe & 4 \\
\hline
\end{tabular}

$\mathrm{CH}$, chronic hepatitis; $\uparrow \mathrm{ALT}$, fluctuating pattern of alanine aminotransferase elevation (ALT 1.2-1.5 of normal values); DVA, degree of villous atrophy; nd, not determined.

*Time (months) of AAA negativity after a gluten free diet.

gluten sensitive liver involvement, represented by mild chronic hepatitis ${ }^{18}$ in six patients or a fluctuating pattern of elevation of alanine aminotransferase (1.2-1.5 normal values). Three had associated insulin dependent diabetes mellitus and four were affected by Down's syndrome. Sixteen patients with antismooth muscle antibody (SMA) positive autoimmune hepatitis $(\mathrm{AH})$, seven with small bowel bacterial overgrowth, 21 with inflammatory bowel diseases (IBD) (12 with Crohn's disease and nine with ulcerative colitis) and 60 sex and age matched healthy volunteers were used as controls.

The AH and IBD patients were receiving immunosuppressive treatments (prednisone alone or associated with azathioprine). Detection of AGA, AEA, and antiactin antibodies (AAA) was therefore performed retrospectively on sera collected and stored at $-20^{\circ} \mathrm{C}$ before a gluten free diet (GFD) (CD patients) or immunosuppressive therapy (AH, IBD), with blinded evaluation.

The mouse monoclonal antitissue transglutaminase antibody (NeoMarkers, Union City, California, USA) and the affinity isolated rabbit AAA (Sigma Chemical, St Louis, Missouri, USA) were used as positive controls in all experiments.

INDIRECT IMMUNOFLUORESCENCE (IF)

Unfixed tissue sections (monkey oesophagus sections, ImmunoPharmacology Research Spa, CT, Italy, for AEA detection; rat kidney, liver and stomach sections, Scimedx, Denville, New Jersey, USA, for SMA, ARA, antiliver kidney microsome antibody (LKM), antiliver cytosol 1 antibody (LC-1), and antimitochondrial antibody (AMA) detection; HEp-2 cells, MarDx diagnostics, Carlsbad, California, USA, for antinuclear antibody (ANA) and AAA detection; and ethanol and formaldehyde fixed neutrophils, Euroimmun, Lubeck, Germany, for antineutrophil cytoplasm antibody (ANCA) detection) were incubated at room temperature for 30 minutes with serum serial dilutions (from 1:5 to 1:1280 for AEA and ANCA, and from $1: 40$ to $1: 1280$ for all other autoantibodies) in a covered moist chamber, washed twice in phosphate buffered saline (PBS) solutions for five minutes, incubated at room temperature for 30 minutes with FITC conjugate goat antihuman sera $(\operatorname{IgA}+\operatorname{IgG}+\operatorname{Ig} M$ or anti-IgA or anti-IgG, Kallestad, Austin, Texas, USA) diluted 1:100 in PBS, washed twice as before, and read with an Orthoplan fluorescence microscope (Leitz, Wetzlar, Germany).

The mouse monoclonal anti-TG antibody and the rabbit AAA were used at a 1:50 dilution during the first incubation followed by a second incubation with the 1:100 diluted FITC conjugate antimouse or antirabbit immunoglobulins (Sigma).

\section{ENZYME IMMUNOASSAY (ELISA)}

Detection of AGA was performed using a commercial kit (Pharmacia and Upjohn Diagnostic AB, Uppsala, Sweden). Detection of antitransglutaminase antibodies (TGA) and AAA was performed using an ELISA as described previously. ${ }^{19}$ Flat bottomed well microtitre plates (Greiner Laboratory, Greiner, Germany) were coated with a $10 \mu \mathrm{g} / \mathrm{ml}$ PBS solution $(50 \mu \mathrm{l} /$ well $)$ of bovine muscle actin 

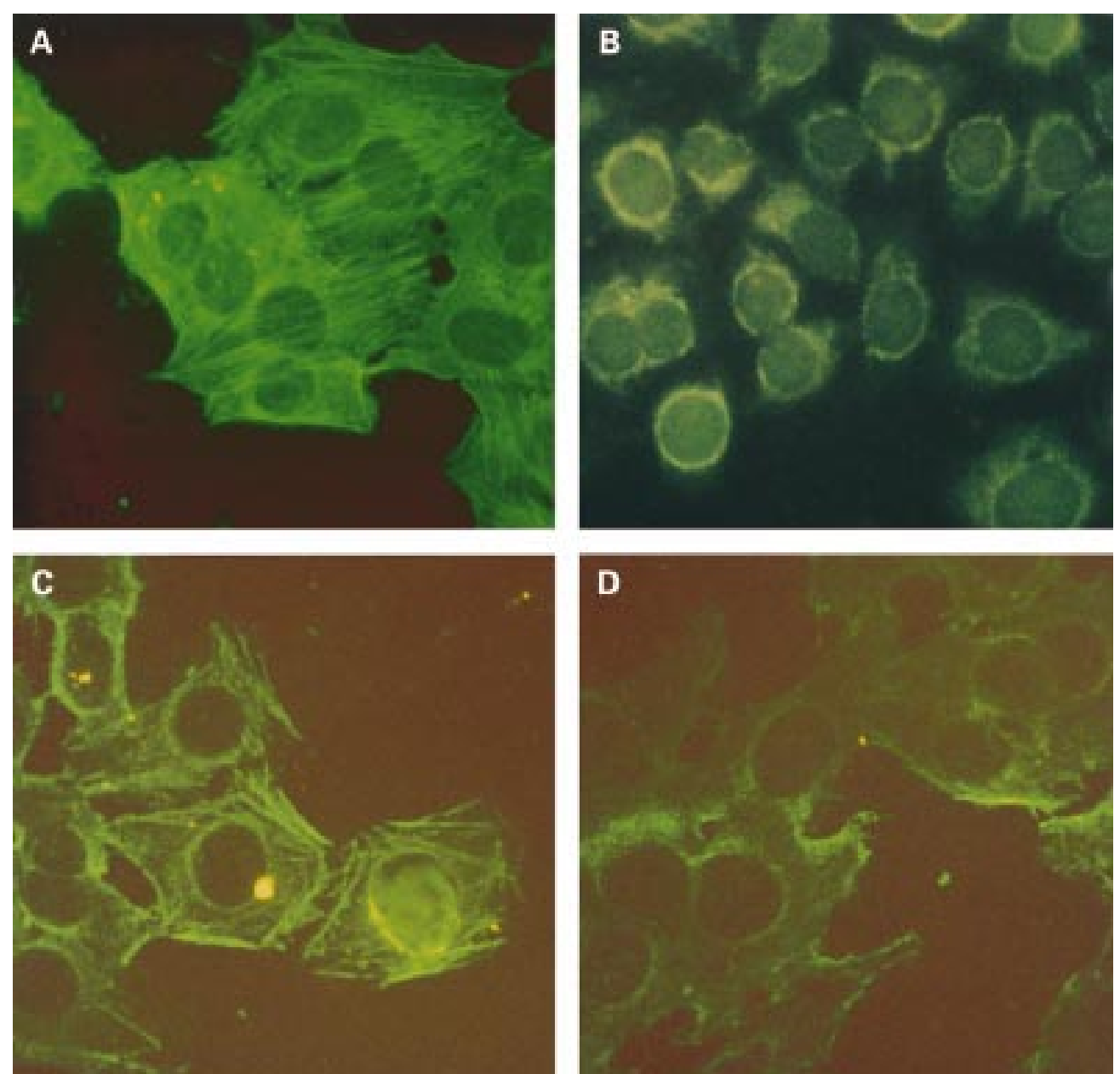

Figures 1 Actin stress fibre immunostaining pattern in indirect immunofluorescence of HEp-2 cells using serum from patient No 21 (see table 1), at a screening dilution of 1:40, and the FITC conjugate antihuman IgA (photomicrograph images, $\times 50 ;(A))$. Typical actin stress fibres appear as long cytoplasmic parallel filaments. (B) Negative immunostaining image obtained using monoclonal antitransglutaminase antibody on HEp-2 cells (photomicrograph images, $\times 50)$. The results of actin absorption experiments using 1:1000 diluted serum are shown in (C) (before absorption) and (D) (after absorption).

(Sigma) or guinea pig liver transglutaminase (Sigma). Stopped reactions were read at 492 nm by a microtitre plate reader (DPC, USA). The normal mean value $(\mathrm{N})$ displayed by healthy control sera was $0.050(0.020)$ (median $0.050)$. The threshold was fixed at $2 \mathrm{~N}(0.100)$. The control wells (no serum) introduced in each plate displayed an absorbance of $<0.025$. A serum sample was considered positive when it exceeded twice $(>0.100)$ the absorbance mean value observed with normal control sera.

\section{WESTERN BLOTTING}

Purified proteins (bovine muscle actin and guinea pig liver transglutaminase; Sigma) were separated by $10 \%$ sodium dodecyl sulphatepolyacrylamide gel electrophoresis and transferred onto nitrocellulose filters. ${ }^{19}{ }^{20}$ The filters were blocked for one hour in a PBS $0.1 \%$ Tween 20, 5\% non-fat dry milk solution, incubated for one hour at room temperature with patients' sera at a 1:100 dilution and successively incubated for one hour at room temperature with a 1:1000 dilution of alkaline phosphatase conjugated antihuman IgG+IgM+IgA antiserum (ICN Biomedicals, Aurora, Ohio, USA). The NBT/BCIP detection system
(Promega, Madison, Wisconsin, USA) was used to develop the filters. ${ }^{20}$

The mouse anti-TG and rabbit AAA were used at a 1:100 dilution, the alkaline phosphatase conjugate antimouse or antirabbit immunoglobulins (Sigma) at 1:1000 dilution.

ABSORPTION EXPERIMENTS

Absorption experiments were performed with bovine muscle actin $^{21}$ and guinea pig liver transglutaminase, ${ }^{9}$ separately, using five sera positive for both TGA and AAA. Sera were incubated overnight under continuous shaking with bovine muscle actin or guinea pig liver transglutaminase at a concentration of $10-$ $100 \mathrm{mg}$ of protein $/ \mathrm{ml}$ of undiluted serum. The solution was then ultracentrifuged at $100000 \mathrm{~g}$ for 30 minutes.

IF of HEp-2 cells was carried out before and after absorption sera with bovine muscle actin or tTG.

HISTOLOGICAL EVALUATION

The degree of crypt hyperplastic villous atrophy was evaluated according to Murch and Phillips $^{22}$ as follows: villous height greater than crypt depth (normal mucosa); villous height 
Table 2 Major serological, clinical, and histological features of antiactin antibody (AAA) positive adults with coeliac disease

\begin{tabular}{|c|c|c|c|c|c|c|c|c|}
\hline $\begin{array}{l}\text { Patient } \\
\text { No }\end{array}$ & $\begin{array}{l}\text { Age (y) at } \\
\text { diagnosis }\end{array}$ & $\begin{array}{l}A E A \operatorname{Ig} A \\
\text { titre }\end{array}$ & $\begin{array}{l}\text { TGA } \operatorname{Ig} A \\
\text { titre }\end{array}$ & $\begin{array}{l}A A A \operatorname{Ig} A \\
\text { titre }\end{array}$ & $\begin{array}{l}\text { AAA } \operatorname{Ig} G \\
\text { titre }\end{array}$ & Liver disease & $D V A$ & $\begin{array}{l}\text { Months of } A A A \\
\text { negativity }\end{array}$ \\
\hline 1 & 17 & $1: 160$ & 0.290 & $1: 160$ & Negative & Absent & Moderate & 3 \\
\hline 2 & 18 & $1: 1280$ & 0.124 & $1: 40$ & Negative & Absent & Severe & nd \\
\hline 3 & 19 & $>1: 1280$ & 0.359 & $>1: 1280$ & Negative & Absent & Severe & nd \\
\hline 4 & 20 & $1: 1280$ & 0.231 & $1: 160$ & Negative & Absent & Severe & nd \\
\hline 5 & 21 & $1: 640$ & 0.470 & Negative & $1: 40$ & Absent & Moderate & 3 \\
\hline 6 & 21 & $>1: 1280$ & 1.140 & $1: 640$ & Negative & Absent & Severe & 4 \\
\hline 7 & 24 & $>1: 1280$ & 0.757 & $>1: 1280$ & Negative & Absent & Severe & nd \\
\hline 8 & 25 & $1: 1280$ & 0.278 & $1: 340$ & Negative & Absent & Severe & nd \\
\hline 9 & 25 & $1: 1280$ & 0.404 & $1: 40$ & Negative & Absent & Severe & nd \\
\hline 10 & 26 & $1: 1280$ & 0.111 & $1: 160$ & Negative & Absent & Severe & nd \\
\hline 11 & 26 & $>1: 1280$ & 0.590 & $1: 160$ & Negative & Absent & Severe & 4 \\
\hline 12 & 26 & $>1: 1280$ & 0.600 & $1: 160$ & $1: 160$ & Absent & Moderate & 3 \\
\hline 13 & 27 & $1: 1280$ & 0.127 & $1: 160$ & Negative & Absent & Severe & nd \\
\hline 14 & 27 & $>1: 1280$ & 1.001 & $>1: 1280$ & Negative & $\mathrm{CH}$ & Moderate & 3 \\
\hline 15 & 28 & $1: 1280$ & 0.145 & $1: 40$ & Negative & Absent & Severe & nd \\
\hline 16 & 29 & $>1: 1280$ & 1.145 & $1: 640$ & Negative & $\mathrm{CH}$ & Severe & 4 \\
\hline 17 & 30 & $1: 1280$ & 0.188 & $1: 40$ & Negative & Absent & Severe & nd \\
\hline 18 & 31 & $1: 1280$ & 0.221 & $1: 160$ & $1: 160$ & Absent & Severe & nd \\
\hline 19 & 31 & $1: 1280$ & 0.552 & $1: 80$ & Negative & Absent & Severe & nd \\
\hline 20 & 32 & $>1: 1280$ & 0.190 & 1:40 & Negative & Absent & Severe & nd \\
\hline 21 & 33 & $1: 1280$ & 0.185 & $>1: 1280$ & $1: 640$ & Absent & Severe & nd \\
\hline 22 & 34 & $>1: 1280$ & 0.710 & $1: 640$ & Negative & $\mathrm{CH}$ & Severe & 4 \\
\hline 23 & 35 & $1: 1280$ & 0.147 & $1: 80$ & Negative & Absent & Severe & nd \\
\hline 24 & 35 & $1: 1280$ & 0.960 & $1: 640$ & $>1: 640$ & Absent & Severe & nd \\
\hline 25 & 45 & $>1: 1280$ & 0.950 & $1: 640$ & Negative & $\mathrm{CH}$ & Severe & 4 \\
\hline 26 & 54 & $1: 1280$ & 0.116 & $1: 40$ & Negative & Absent & Severe & nd \\
\hline 27 & 55 & $1: 320$ & 0.313 & $1: 40$ & $1: 40$ & $\mathrm{CH}$ & Severe & 4 \\
\hline 28 & 65 & $1: 1280$ & 0.132 & $1: 40$ & Negative & Absent & Severe & nd \\
\hline
\end{tabular}

$\mathrm{CH}$, chronic hepatitis; DVA, degree of villous atrophy; nd, not determined.

*Time (months) of AAA negativity after a gluten free diet.

and crypt depth approximately equal (mild villous atrophy); crypt depth greater than villous height (moderate villous atrophy); and flat mucosa in which villi are no longer detectable (severe villous atrophy).

STATISTICAL ANALYSIS

Associations were performed using Fisher's exact test. Relative risk (RR) was calculated using the Sheehe method. Correlation was measured using the Spearman correlation coefficient $\left(r_{\mathrm{s}}\right)$ and the Goodman-Kruskal gamma statistics test. Tests were considered significant if $\mathrm{p}<0.05$.

\section{Results}

ANTIACTIN ANTIBODIES (AAA)

Fifty nine of $83(71 \%)$ untreated CD patients were positive for IgA and/or IgG AAA by IF of HEp- 2 cells (table 1 ). AAA were detected more frequently in adults than children $(90.3 \% v$ $\left.59.6 \% ; r_{\mathrm{s}} 0.247 ; \mathrm{p}=0.025\right)$. Figure $1 \mathrm{~A}$ shows typical AAA immunostaining where the actin filaments appear as long parallel filaments spanning the axis of cells and crossing the nucleus. IF of HEp-2 cells performed with the monoclonal anti-tTG antibody did not show any positivity (fig $1 \mathrm{~B}$ ).

Actin stress fibre immunostaining disappeared almost completely after absorption with bovine muscle actin (fig 1C, 1D) but remained unchanged after absorption with tTG (data not shown), confirming the antigen specificity of this reaction.

The major serological, clinical, and histological features of AAA positive and AAA negative coeliac patients are shown in tables $1-3$. Fifty patients $(60.2 \%)$ were positive for IgA type AAA (titre range $1: 40$ to $1: 1280$ ) while $21(25.3 \%)$ were positive for IgG type
AAA (titre range $1: 40$ to $1: 640$ ). Thirty eight $(45.7 \%)$ were IgA positive, nine $(10.8 \%)$ were IgG positive, and $12(14.4 \%)$ were both IgA and IgG positive. IgA type AAA correlated with serum total IgA $\left(r_{\mathrm{s}} 0.674 ; \mathrm{p}=0.0001\right)$ while IgG type AAA did not correlate with serum total $\operatorname{IgG}(\mathrm{ns})$.

AAA disappeared in all patients within the first five months on a GFD (tables 1, 2, 3), that is, later than AGA but earlier than AEA (data not shown).

Eighteen of 59 coeliac sera reacted with monomeric actin, as demonstrated by western blotting and ELISA. Figure 2 shows the results of western blotting obtained with sera from coeliac patient Nos 13 (see table 3) and 2 (see table 2). Sera reacted distinctly with the $78 \mathrm{kDa}$ protein band of tTG (fig 2, No 2) and with the $42 \mathrm{kDa}$ protein band of the monomeric actin (fig 2, No 4).

A high correlation ( $r_{\mathrm{s}}$ 0.64; gamma 0.90; $\mathrm{p}<0.0001)$ was observed between AAA positivity and the degree of histological villous atrophy, with 49 AAA positive patients showing severe and 10 moderate degrees of villous atrophy (tables 1, 2, 3). The presence of AAA has been estimated at $16.7 \mathrm{RR}$ (95\% confidence interval 5.44-51.32) for severe compared with moderate or mild degrees of villous atrophy, and at $86.17 \mathrm{RR}$ (95\% confidence interval 10.30-720.7) for moderate or severe compared with mild degrees of villous atrophy.

AAA were found in $16 / 19$ coeliac patients $(84.2 \%)$ with associated hepatopathy at clinical presentation (tables 1, 2, 3). Fourteen patients (73.6\%) were positive for IgA type AAA (titre range $1: 40$ to $1: 1280)$ while nine $(47.3 \%)$ were positive for IgG type AAA (titre range 1:40 to $1: 640)$. Seven (36.8\%) were IgA positive, two $(10.5 \%)$ were $\operatorname{IgG}$ positive, and seven $(36.8 \%)$ 
Table 3 Major serological, clinical, and histological features of antiactin antibody $(A A A)$ negative children and adults with coeliac disease

\begin{tabular}{llclll}
\hline $\begin{array}{l}\text { Patient } \\
\text { No }\end{array}$ & $\begin{array}{l}\text { Age }(y) \text { at } \\
\text { diagnosis }\end{array}$ & AEA IgA titre & TGA IgA titre & Liver disease & DVA \\
\hline 1 & 1 & $1: 160$ & 0.050 & Absent & Mild \\
2 & 2 & $1: 640$ & 0.372 & Absent & Mild \\
3 & 3 & $1: 640$ & 0.072 & Absent & Moderate \\
4 & 3 & $>1: 1280$ & 1.038 & Absent & Severe \\
5 & 3 & $1: 640$ & 0.280 & Absent & Mild \\
6 & 4 & $1: 160$ & 0.102 & $\uparrow$ ALT & Moderate \\
7 & 4 & $>1: 1280$ & 0.500 & $\uparrow$ ALT & Moderate \\
8 & 4 & $>1: 1280$ & 0.039 & Absent & Mild \\
9 & 5 & $>1: 1280$ & 0.380 & $\uparrow$ ALT & Moderate \\
10 & 5 & $1: 160$ & 0.235 & Absent & Mild \\
11 & 5 & $>1: 1280$ & 0.410 & Absent & Severe \\
12 & 6 & $>1: 1280$ & 0.790 & Absent & Mild \\
13 & 6 & $>1: 1280$ & 0.710 & Absent & Severe \\
14 & 6 & $1: 160$ & 0.275 & Absent & Mild \\
15 & 7 & $1: 1280$ & 0.400 & Absent & Mild \\
16 & 7 & $1: 320$ & 0.460 & Absent & Moderate \\
17 & 8 & $>1: 1280$ & 0.118 & Absent & Mild \\
18 & 9 & $1: 640$ & 0.990 & Absent & Mild \\
19 & 9 & $1: 640$ & 0.790 & Absent & Moderate \\
20 & 10 & $1: 640$ & 0.700 & Absent & Moderate \\
21 & 10 & $1: 160$ & 0.446 & Absent & Severe \\
22 & 34 & $>1: 1280$ & 0.630 & Absent & Severe \\
23 & 34 & $1: 640$ & 0.298 & Absent & Moderate \\
24 & 40 & Absent & Moderate \\
\hline
\end{tabular}

个ALT, fluctuating pattern of alanine aminotransferase elevation (ALT 1.2-1.5 of normal values); DVA, degree of villous atrophy.

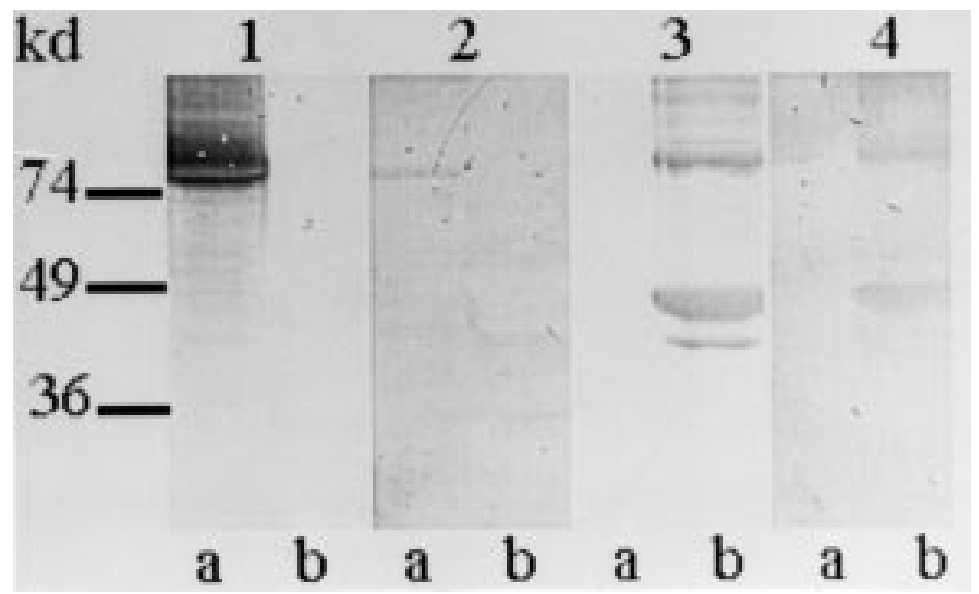

Figure 2 Western blotting with guinea pig liver tissue transglutaminase ( $t$ TG) (lines a) and bovine muscle actin (lines $b$ ). No 1: monoclonal anti-tTG antibody; No 2: serum from coeliac patient No 13 (see table 3); No 3: antiactin affinity antibody; No. 4: serum from coeliac patient No 2 (see table 2). Molecular mass is shown on the left.

were both IgA and IgG positive. No association was found between AAA positivity (IgA and/or $\mathrm{IgG})$ and the presence of liver involvement at clinical presentation (ns).

ANTISMOOTH MUSCLE ANTIBODIES

SMA antibodies were detected in $49.4 \%$ of our CD patients by IF on rat liver, kidney, and stomach sections. ${ }^{23}$ Titre was $\leqslant 1: 80$ in $85.4 \%$ of patients (titre range $1: 40$ to $1: 320$, median $1: 40)$.

Eighty four per cent of SMA positive patients were also AAA positive while $15.4 \%$ were AAA negative. However, there was only a weak correlation ( $r_{\mathrm{s}}$ 0.27; gamma 0.57) between SMA and $\mathrm{AAA}$ as $42 \%$ of AAA positive patients showed no evidence of SMA. No correlation was found between SMA and degree of villous atrophy $\left(r_{\mathrm{s}} 0.068\right.$, ns; gamma $\left.0.130, \mathrm{~ns}\right)$.

ANTITRANSGLUTAMINASE ANTIBODIES

Seventy seven $(92.7 \%)$ coeliac patients reacted with tTG, as demonstrated by ELISA (tables
1-3). Antiendomysium positive patients showed a mean absorbance value of 0.556 (0.405) (median 0.453; range 0.04-1.48). A correlation was found between IgA-TGA and serum total IgA $\left(r_{\mathrm{s}} 0.778 ; \mathrm{p}=0.0001\right)$. No correlation was found between IgA-AAA and IgATGA (ns).

ANA, ANCA, LKM, AMA, LC-1, AND SLA ANTIBODIES Twenty three $(27.7 \%)$ CD patients were ANA positive. No association was found between ANA positivity and degree of villous atrophy (ns) or the presence of liver involvement (ns).

None of the coeliac patients was positive for ANCA, LKM, AMA, antisoluble liver antigen antibodies (SLA), or LC-1 antibodies.

CONTROL GROUPS

AH patients

All 16 SMA positive $\mathrm{AH}$ patients enrolled in the study were AAA positive. AAA were of the IgG type in all patients (titre range 1:40 to $>1: 1280)$. Only two AH patients reacted with monomeric actin on western blotting or ELISA (data not shown). None was positive for AGA and/or AEA. Eighty five per cent of $\mathrm{AH}$ patients were also pANCA positive.

IBD patients, small bowel bacterial overgrowth, and healthy controls

None of the IBD, small bowel overgrowth, or healthy controls was IgA-AAA positive. Two of nine patients with ulcerative colitis showed IgG-AAA at low titre (1:5). ANCA were positive in five patients with ulcerative colitis (pANCA) and in three patients with Crohn's disease (two pANCA, one cANCA).

\section{Discussion}

We have described for the first time gluten dependent serum autoantibodies against actin in CD. This immune reaction is clearly distinct from those of the extracellular matrix of the lamina propria and the endomysium of muscularis mucosa, whose main target antigen has recently been identified as tTG. ${ }^{9}$ In predisposed subjects, tTG by gliadin deamidation and by the formation of the gliadin-tTG complex may enhance mucosal $\mathrm{T}$ cell activation and production of cytokines and matrix metalloproteinases that cause damage to the intestinal mucosa. ${ }^{10-12}$

The immune reaction against the cytoskeleton in our CD patients was found to be associated with more severe degrees of intestinal villous atrophy, and to be age related as it was observed more frequently in our CD adult patients than in children. The close link between the presence of AAA and the severity and persistence of tissue damage suggests that AAA could be secondary to intestinal mucosa damage in that it unmasks cryptic antigens. According to this hypothesis other tissue antigens may become increasingly exposed to the immune system as a result of continued gluten ingestion thus leading to the production of increasing numbers of autoantibodies in predisposed subjects. Indeed, autoantibodies against human calreticulin, an endoplasmic reticulum luminal protein, ${ }^{24}$ and recently auto- 
antibodies against zonulin, a newly described enterocyte protein, have been detected in untreated CD patients. ${ }^{25}$ Moreover, preliminary results from our study (data not shown) reveal the presence of IgA antibodies to gelsolin, an actin severing and capping protein, in $30 \%$ of AAA positive CD patients (unpublished results).

Furthermore, gluten challenge in CD patients has been described as causing a very early reduction and disorganisation of enterocyte actin filaments. ${ }^{14}{ }^{15}$ Thus impairment of the cytoskeleton network per se could induce further mucosal damage and apoptosis, ${ }^{26-28}$ aggravating immune mediated tissue damage. In fact, the activity of genes encoding for proteins involved in the structure (type I collagen and fibronectin), turnover (collagenase and tissue inhibitor of metalloproteinase 1), and regulation (transforming growth factor $\beta$ ) of the extracellular matrix is governed, at least partly, by the status of the cytoskeleton. ${ }^{29}$

Moreover, as serum AAA positivity has been found to have a high RR for severe villous atrophy, AAA could represent a useful serological marker of intestinal mucosal damage in coeliac patients.

In our study, among the intestinal diseases characterised by immuno mediated tissue damage, IgA-AAA appear to be associated with $C D$, while they are negative in IBD, which are predominantly characterised by IgG-pANCA. ${ }^{30}$ Only two IBD patients showed AA autoantibodies; however, they were of the IgG type, at a low titre, and not associated with AEA or TGA.

Liver involvement in our CD patients is another moot point. The problem of liver damage in association with CD has been outlined since 1977, and serological screening for antigliadin has long been recommended in patients with cryptogenic hepatitis. ${ }^{31-33}$ Nevertheless, complete analysis of the major autoantibodies that characterise the various forms of chronic hepatitis (that is, ANA, SMA, AAA, LKM, AMA, SLA, LC-1, and ANCA) ${ }^{18}$ has never been carried out in $\mathrm{CD}^{33}$ In our study most coeliac patients with associated liver involvement had positive AAA of either the IgG or the IgA type or both, while analysis of other autoantibodies associated with chronic hepatitis proved negative.

As described in patients affected by $\mathrm{AH},{ }^{34}$ AAA detected in CD seem to be specific for polymerised actin, and IF of fibroblasts or HEp-2cells represents the most widely used method of AAA detection. ${ }^{34}{ }^{35}$ In fact only a few of our patients, in the $\mathrm{CD}$ and $\mathrm{AH}$ groups, reacted with unpolymerised actin in the western blotting and ELISA experiments. This may be attributable to the high epitope density in polymerised actin. ${ }^{21}$ The monomeric actin that produced negative results on ELISA and western blotting was the same form of protein that allowed preabsorption of patient sera. It may be contradictory, but the high monomeric actin concentration used for absorption experiments promotes the formation of actin filaments. $^{36}$
While in $\mathrm{AH}, \mathrm{IgG} \mathrm{AAA}$ were the most predominant class, AAA in CD were mostly of the IgA type. Furthermore, unlike severe hepatitis in $\mathrm{AH}$ patients, chronic hepatitis in all our coeliac patients was mild, with no hypergammaglobulinaemia, and responsive to a GFD. Therefore, a diagnosis of CD should be considered based on AGA and AEA investigations in all patients with chronic hepatitis, particularly in the presence of AAA positivity. A small bowel biopsy in positive patients will allow selection of patients that should be placed on a GFD.

In conclusion, our study is the first to describe an immune reaction against actin filaments in children and adult CD patients. From a practical point of view, the availability of a further serological marker could be useful in directing diagnostic suspicion towards CD. Further studies will help confirm the presence of AAA in the sera of coeliac patients as a marker of moderate or severe intestinal mucosal villous atrophy.

Contributors: Professor Stefano De Virgiliis and Dr Maria Grazia Clemente were the principal investigators in the design of the study. They wrote the paper together with Professor Roberto Gino Corazza. The former two followed children with $\mathrm{CD}$ from a clinical point of view, while Professor Corazza and $\mathrm{Dr}$ Giovanna Brusco followed adult patients. Dr Clemente, Dr Maria Paola Musu and Dr Fulvia Frau performed autoantibody detection by indirect immunofluorescence, western blotting detection by indirect immunofluorescence, western blotting, and ELISA. Dr Gabriella Sole carried out the statistical analysis. All investigators read and contributed to successive drafts of
the paper. the paper.

We are grateful to Professor Antonio Cao for advice and helpful discussion. The work was partially supported by a grant from the Assessorato Igiene, Sanità e Assistenza Sociale, Regione Autonoma della Sardegna, Cagliari and from the Ministero dell'Università e della Ricerca Scientifica e Tecnologica (quota $40 \%$ ), Roma, Italy.

1 Trier JS. Diagnosis of celiac sprue. Gastroenterology 1998;115:211-16.

2 Unsworth DJ, Walker-Smith JA, Holborow EJ. Gliadin and reticulin antibodies in childhood coeliac disease. Lancet 1983;1:874-5.

3 Chorzelski TP, Sulej J, Tchorzewska $\mathrm{H}$, et al. IgA class endomysium antibodies (IgA-EmA) in dermatitis herpetiformis and coeliac disease. Ann NY Acad Sci 1983;420: 324-5.

4 Mäki M, Collin P. Coeliac disease. Lancet 1997;349:1755-9.

5 Sollid LM, Markussen G, Ek J, et al. Evidence for a primary Sollid LM, Markussen G, Ek J, et al. Evidence for a primary
association of coeliac disease to a particular HLA-DQ $\alpha / \beta$ heterodimer. F Exp Med 1989;169:345.

6 Ventura A, Magazzu G, Greco L. Duration of exposure to gluten and risk for autoimmune disorders in patients with celiac disease. SIGEP Study Group for Autoimmune Disorders in Celiac Disease. Gastroenterology 1999;117:297303.

7 Walker-Smith JA, Guandalini S, Schmitz J, et al. Revised criteria for diangosis of celiac disease. Arch Dis Child 1990; 65:909-11.

8 Marsh MN. Transglutaminase, gluten and coeliac disease: food for thought. Nat Med 1997;3:725-6.

9 Dieterich W, Ehnis T, Bauer M, et al. Identification of tissue transglutaminase as the autoantigen of coeliac disease. Nat Med 1997;3:797-801.

10 Molberg O, Mcadam SN, Korner R, et al. Tissue transglutaminase selectively modifies gliadin peptides that are recognized by gut-derived T cells in coeliac disease. Nat are recognized by gut-dic

11 Pender SLF, Tickle SP, Docherty AJ, et al. A major role for matrix metalloproteinases in $\mathrm{T}$ cell injury in the gut. $f$ Immunol 1997;158:1582-90.

12 Schuppan D, Dieterich W, Riecken EO. Exposing gliadin as a tasty food for lymphocytes. Nat Med 1998;4:666-7.

13 Sjolander A, Magnusson KE. Effects of wheat germ agglutinin on the cellular content of filamentous actin in intestine 407 cells. Eur f Cell Biol 1988;47:32-5.

14 Bailey DS, Freedman AR, Price SC, et al. Early biochemical responses of the small intestine of coeliac patients to wheat gluten. Gut 1989;30:78-85.

15 Holmgren-Peterson K, Magnusson KE, Stenhammar L, et al. Confocal laser scanning microscopy of small-intestinal mucosa in coeliac disease. Scand $\mathcal{F}$ Gastroenterol 1995;30: 228-34.

16 Chowdhury ZA, Barsigian C, Cilalupowicz GD, et al. Colocalization of tissue transglutaminase and stress fibers in
human vascular smooth muscle cells and human umbilical vein endothelial cells. Exp Cell Res 1997;231:33-49. 
17 Mays RW, Beck Ka, Nelson WJ. Organization and function of the cytoskeleton in polarized epithelial cells-a component of the protei

18 Desmet VJ, Gerber M, Hoofnagle HJ, et al. Classification of chronic hepatitis: diagnosis, grading and staging. Hepatology 1994;19:1513-20.

19 Sulkanen S, Halttunen T, Laurila $\mathrm{K}$, et al. Tissue transglutaminase autoantibody enzyme-linked immunosorbent assay in detecting celiac disease. Gastroenterology 1998;115:1322-8.

20 Clemente MG, Meloni A, ObermayerStraub P, et al. Two cytochromes P450 are major hepatocellular autoantigens in autoimmune polyglandular syndrome type 1. Gastroenterology 1998;114:324-8.

21 Kurki P, Linder E, Miettinen A, et al. Smooth muscle antibodies of actin and non-actin specificity. Clin Immunol Immunopathol 1978;9:443-53.

22 Murch SH, Phillips AD. Small intestinal biopsy. In: Walker WA, Durie PR, Hamilton RJ, et al, eds. Pediatric WA, Durie PR, Hamilton RJ, et al, eds. Pediatric
gastrointestinal disease, 2nd edn. St Louis: Mosby, 1996: gastrointestin

23 Bottazzo GF, Florin-Christensen A, Fairfax A, et al. Classification of smooth muscle autoantibodies detected by immunofluorescence. $\mathcal{F}$ Clin Pathol 1976;29:403-10.

24 Karska K, Tuckova L, Steiner L, et al. Calreticulin : the potential autoantigen in celiac disease. Biochem Biophys Res Commun 1995;209:597-605.

25 Fasano A, Not T, Wang W, et al. Zonulin, a newly discovered modulator of intestinal permeability, and its expression in coeliac disease. Lancet 2000;355:1518-19.

26 Kayalar C, Örd T, Testa MP, et al. Cleavage of actin by interleukin 1 beta-converting enzyme Dnase I inhibition. Proc Natl Acad Sci USA 1996;93:2234-8.
27 Tomasek JJ, Halliday NL, Updike DL, et al. Gelatinase A activation is regulated by the organization of the polymer-

28 Leeve MG, Dabrowska MI, Lelli JL, et al. Actin polymerization and depolymerization during apoptosis in HL-60 cells. Am F Physiol 1996;271:C1981-92.

29 Varedi M, Ghahary A, Scott PG, et al. Cytoskeleton regulates expression of genes for transforming growth actor-beta 1 and extracellular matrix proteins in dermal fibroblasts. F Cell Physiol 1997;172:192-9.

30 Terjung B, Herzog V, Worman HJ et al. Atypical antineutrophil cytoplasmic antibodies with perinuclear fluorescence in chronic inflammatory bowel diseases and hepatobiliary disorders colocalize with nuclear lamina proteins. Hepatology 1998;28:332-40.

31 Hagander B, Berg NO, Brandt L, et al. Hepatic injury in adult coeliac disease. Lancet 1977;2:270-2.

32 Vajro P, Fontanella A, Mayer M, et al. Elevated serum aminotransferase activity as an early manifestation of aminotransferase activity as an early manifestation

33 Volta U, De Franceschi L, Lari F, et al. Coeliac disease hidden by cryptogenic hypertransaminasaemia. Lancet 1998; 352:26-9.

34 Cançado ELR, Vilas-Boas LS, Abrantes-Lemos CP, et al. Heat serum inactivation as a mandatory procedure for antiactin antibody detection in cell culture. Hepatology 1996;23:1098-104.

35 Czaja AJ, Cassani F, Cataleta $M$, et al. Frequency and ignificance of antibodies to actin in type 1 autoimmune hepatitis. Hepatology 1996;24:1068-73.

36 Cooper JA. Actin filaments assembly and organization in vitro. In: Carraway KL, Carraway AC, ed. The cytoskeleton. A pratical approach. Oxford: Oxford University Press, 1992: 47-71. 